Research Article

\title{
PRODUCTION OF AA7075/B4C COMPOSITE MATERIALS BY THE SEMI-SOLID STIRRING METHOD
}

\author{
Rifat YAKUT ${ }^{1^{*}}$, Nilhan ÜRKMEZ TAŞKIN ${ }^{2}$
}

\begin{abstract}
AA7075 aluminum alloy was reinforced with $B{ }_{4} C$ particles to produce aluminum composite materials. In the production of $A A 7075 / B{ }_{4} C$ composite materials, the semi-solid mixing method was used for homogenous reinforcement dispersion and low-pressure solidification. For determination of the mechanical properties of the obtained samples, three-point bending, compression and hardness tests were performed. Additionally, the microstructure, reinforcement matrix interface and chemical structure of the produced composite material were investigated by scanning electron microscopy (SEM), energy dispersive X-ray spectrometry (EDS) and X-ray diffraction (XRD) analyses. As a result, it was observed that, by using the semi-solid mixing method, the reinforcing powders could be distributed homogeneously into the matrix, both chemical and mechanical bonding could be facilitated between the matrix and the reinforcing material, and this mixing technique could be easily used in production of particle-reinforced metal composites. As the reinforcement rate increased, bending strength increased, but there was a reduction in comparison to the non-reinforced aluminum alloy. As the reinforcement rate increased, compressive strength was observed to decreased, while the mean hardness value increased.
\end{abstract}

Key words: Aluminum, $B{ }_{4} C$, Metal Matrix Composites, Semi-Solid Stirring

\section{Introduction}

Studies on metal matrix composite materials (MMCs) began in the late 1950s with the aim of maintaining the superior characteristics of metallic materials and improving their structural properties [1]. These materials may be used in different areas based on their intended use [2]. These materials are advanced materials which show superior properties due to ceramic reinforcements that are dispersed into metals or metal alloys. They have found a broad area of application especially in the aerospace and automotive industries. Ceramics such as $\mathrm{SiC}, \mathrm{Al}_{2} \mathrm{O}_{3}, \mathrm{C}, \mathrm{SiO}_{2}, \mathrm{MgO}, \mathrm{TiC}, \mathrm{TiB}_{2}$ and $\mathrm{B}_{4} \mathrm{C}$ are the leading types of reinforcements incorporated into MMCs to improve their mechanical properties. Among these reinforcements, $\mathrm{B}_{4} \mathrm{C}$ has been a subject to many fields recently due to its superior physical and chemical properties, and it is a highly strategic material for Turkey, with its rich boron resources $[3,4,5,6,7]$. Due to the characteristics of metal matrix composite (MMC) materials

\footnotetext{
1 Department of Energy Systems Engineering, University of Batman, Batman, Turkey, (rifat.yakut@batman.edu.tr) iD https://orcid.org/0000-0003-0059-3785

2 Department of Mechanical Engineering, University of Trakya, Edirne, Turkey, (nilhanurkmez@gmail.com) iD https://orcid.org/0000-0003-2251-3889
} 
consisting of a metal matrix and ceramic reinforcements such as high strength, lightness, high abrasion resistance and good thermal expansion coefficients, their usage areas in the automotive, aviation and defense industries are increasingly more frequent [8]. High-tech ceramics, polymers, metals and composites that entered the world's economy with a high market share in the second half of the twentieth century are high-added-value materials [9]. In recent years, particularly aluminum MMCs (Al-MMCs) have been widely investigated and are used in new industrial applications. The widespread use of aluminum as a matrix material is increasing due to its low density and low cost [10, $11,12]$. Moreover, aluminum is an attractive material for production of MMCs due to its corrosion resistance, low electrical resistance and perfect mechanical properties [13, 14]. Production and use of MMCs are increasing with technological advancements, especially in the automotive industry and the aerospace and aviation sectors. By combining the desired properties of two or more identical or different groups of materials one in the form of at least one metal and metal alloy and the other in the form of continuous fiber, capillary crystal or particle, superior MMCs may be produced [15, 16, 17, 18, 19]. MMCs are high-tech materials which can display superior properties such as high tensile strength, high modulus of elasticity, abrasion, compression and creep strength, ability to maintain its stability at high temperatures, ductility and toughness, low specific gravity, low sensitivity to thermal shocks and high electrical and thermal conductivity [20].

\section{Research Significance}

Due to their low density, high melting temperatures, high elasticity and high strength properties, $\mathrm{B}_{4} \mathrm{C}$ ceramic powders are highly preferred in production of high-strength aluminum-based composite materials. In this study, it was firstly aimed to increase the wettability of $\mathrm{B}_{4} \mathrm{C}$ ceramic powders by the AA7075 Aluminum alloy by using the semi-solid stirring method and heat treatment of $\mathrm{B}_{4} \mathrm{C}$ powders. It was targeted to minimize problems such as non-uniform reinforcement distribution in the matrix, agglomeration of the reinforcements and rejection of reinforcement from mixture and improve the properties of the composite material by the using semi-solid stirring method.

\section{Material And Method}

\subsection{Matrix Material}

The AA7075 alloy was selected as the matrix material the production of $\mathrm{B}_{4} \mathrm{C}$-reinforced composite materials. The density of this alloy is $2.8\left(\mathrm{~g} / \mathrm{cm}^{3}\right)$, and it has high strength. Copper is the main alloying element in this alloy, where magnesium, chromium and zirconium are additional alloying elements. Tables 1-2 show the properties of the AA7075 aluminum alloy [21].

Table 1. Mechanical characteristics of AA7075 alloy

\begin{tabular}{|c|c|c|c|c|}
\hline $\begin{array}{c}\text { Heat } \\
\text { Treatment }\end{array}$ & $\begin{array}{c}\text { Tensile Strength, } \\
\text { Rm MPa }\end{array}$ & $\begin{array}{c}\text { Elongation Strength } \\
\text { \% }\end{array}$ & $\begin{array}{c}\text { Shear Modulus } \\
\text { MPa }\end{array}$ & Elasticity Modulus GPa \\
\hline T651 & 572 & 11 & 331 & 72 \\
\hline T7351 & 503 & 13 & 303 & 72 \\
\hline T7651 & 503 & 13 & 303 & 72 \\
\hline
\end{tabular}

Table 2. Chemical composition of AA7075 alloy

\begin{tabular}{|c|c|c|c|c|c|c|c|c|c|}
\hline Weight \% & Weight \% & Si & Fe & $\mathbf{C u}$ & $\mathbf{M g}$ & $\mathbf{M n}$ & $\mathbf{C r}$ & $\mathbf{Z n}$ & Ti \\
\hline Minimum & Minimum & - & - & 1.2 & 2.1 & - & 0.18 & 5.1 & - \\
\hline Maximum & Maximum & 0.4 & 0.5 & 2 & 2.9 & 0.3 & 0.28 & 6.1 & 0.2 \\
\hline
\end{tabular}




\subsection{Reinforcement Materials}

Due to its lightness and superior mechanical properties, $\mathrm{B}_{4} \mathrm{C}$ is used as the reinforcing material to increase the abrasion and impact resistance of materials [22]. The $\mathrm{B}_{4} \mathrm{C}$ material is among the advanced-technology ceramics of today with its characteristics such as high melting temperature, high hardness, high abrasion strength, low density and superior resistance against chemical substances. Its hardness values do not decrease even at temperatures around $1300^{\circ} \mathrm{C}$ [23]. Table 3 shows the properties of $\mathrm{B}_{4} \mathrm{C}$ reinforcing materials.

Table 3. Some mechanical and physical characteristics of $\mathrm{B}_{4} \mathrm{C}$ materials [21].

\begin{tabular}{|l|l|}
\hline Reinforcement Material & $\mathbf{B}_{\mathbf{4}} \mathbf{C}$ \\
\hline Density $\left(\times 10^{3} \mathrm{kgm}^{3}\right)$ & 2.52 \\
\hline Thermal Expansion Coefficient $\left(10^{-6} \mathrm{C}^{-1}\right)$ & 6.08 \\
\hline Melting Point $\left({ }^{\circ} \mathrm{C}\right)$ & 2420 \\
\hline Compression Strength $(\mathrm{MPa})$ & 2900 \\
\hline Elasticity Modulus $(\mathrm{GPa})$ & 460 \\
\hline Knoop Hardness & 2800 \\
\hline
\end{tabular}

\subsection{Composite Material Production by the Method of Semi-Solid Stirring}

The temperature of the melting furnace (Figure 1 (a)) was kept constant in the range of $700{ }^{\circ} \mathrm{C}$ $720^{\circ} \mathrm{C}$. The nitrogen gas introduction setup was installed by means of the mechanism to allow nitrogen gas to be emitted onto the molten metal. After the matrix material was put into a SiC crucible where melting and mixing processes were performed, it was increased to the semi-solid temperature range, and the reinforcement material, heated up to $220{ }^{\circ} \mathrm{C}$, was added with a speed of $5 \mathrm{gr} / \mathrm{min}$. The $\mathrm{B}_{4} \mathrm{C}$ reinforcement was mixed into the matrix at constant temperature by using steel bars with specially profiled stirrers. Homogeneous mixing of the matrix material and reinforcement in the matrix material was ensured without any flocculation by mixing at a low speed by the mixer at a semi-solid temperature. After the reinforcement process was completed, a homogenization process was carried out by applying high-speed mixing to the semi-solid melt for a short time. After the mixing and homogenization processes, the lowest temperature range that provided fluidity was selected as the casting temperature, and the mixture was removed from the melting unit and transferred to the steel molds which had previously been heated to $540-550{ }^{\circ} \mathrm{C}$ (Figure 1 (b)). The mold cap of the melted steel mold was closed, put under a pressure tray and compressed under a pressure process that was started within a few seconds. After applying compressive pressure under $10 \mathrm{MPa}$ for 3-4 seconds, the whole mold was removed from the press, the composite material was allowed to cool in the mold for 15 minutes, and it was removed from the mold and left for cooling at the ambient temperature. The removal process of the prismatic metal matrix composite specimen material from the mold is shown in Figure 1 (c). AA7075/B 4 C composite materials were produced by adding $\mathrm{B}_{4} \mathrm{C}$ reinforcement into the semi-solid aluminum alloy in the ratios specified in Table 4. Temperature measurements were performed by two K-type thermocouples. One of the thermocouples contacted the furnace's interior, and the other was dipped into the mixture in the crucible. Three specimens were produced for each reinforcement ratio. Control specimens were produced under the same production conditions but without reinforcements. 


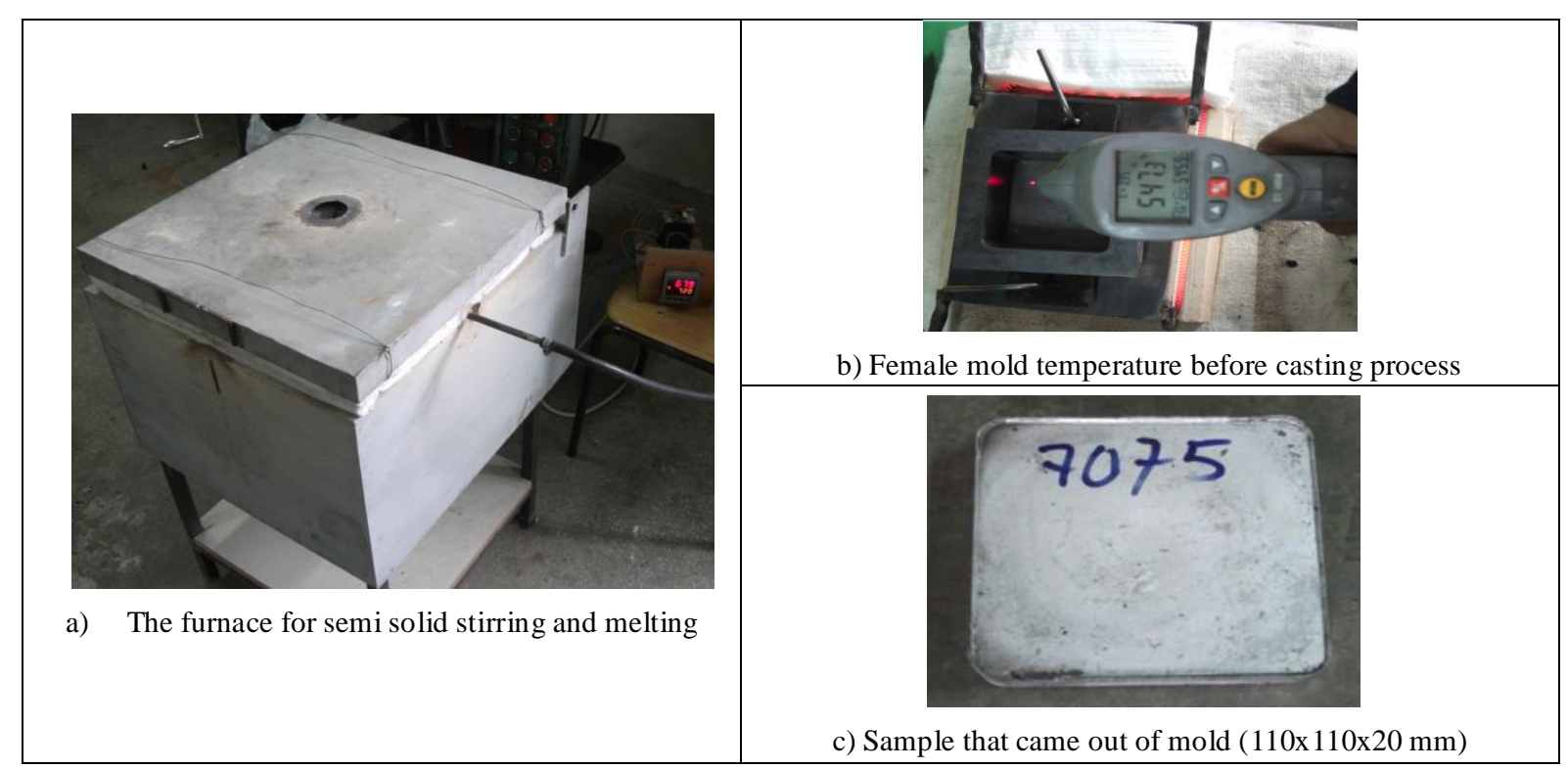

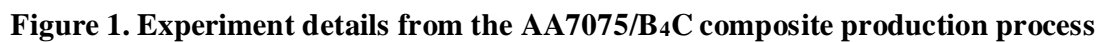

Three-point bending test (TS-205), compression (TS EN ISO 6506-1) and hardness specimens (ASTM-E9) were prepared in accordance with the relevant standards. All specimens were produced with Wire Electrical discharge machining (WEDM) in Hema Industrial Inc. Figure 2 (a), (b), (c) shows the test sample types and preparation details.

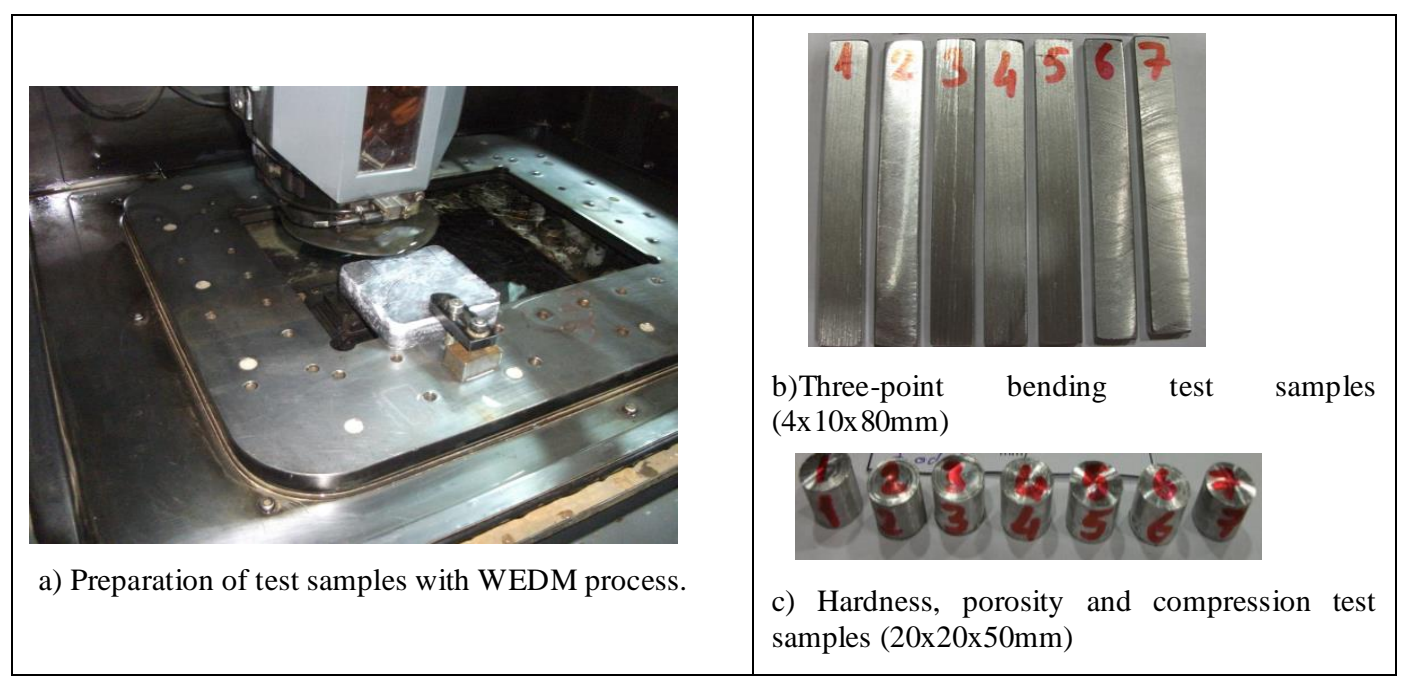

Figure 2. Test sample types and preparation details

\section{Result And Discussion}

In this study, due to its widespread use in industrial fields, the AA7075 aluminum alloy was selected as the matrix material in particular. The $\mathrm{B}_{4} \mathrm{C}$ material selected as the reinforcing material was mixed into the semi-solid aluminum alloy, and composites with different reinforcing ratios were obtained. The effects of the reinforcing ratios of the obtained composites on mixing performance and mechanical properties were investigated. 


\subsection{Specific Weight and Porosity Measurement Results}

The density of the $\mathrm{B}_{4} \mathrm{C}$-particle-reinforced samples was calculated according to the Archimedes principle. The variation of the theoretical and experimental densities of the samples produced depending on the particle ratio is given in Table 4.

Table 4. Theoretical, specific gravities and porosity ratios of the samples

\begin{tabular}{|l|c|c|c|c|}
\hline \multicolumn{1}{|c|}{ Material } & $\begin{array}{c}\text { \%B4C } \\
\text { (by Volume) }\end{array}$ & $\begin{array}{l}\text { Theoretical Specific } \\
\text { Weight }\left(\mathbf{g}_{\mathbf{f}} / \mathbf{c m}^{\mathbf{3}}\right)\end{array}$ & $\begin{array}{l}\text { Experimental Specific } \\
\text { Weight }\left(\mathbf{g}_{\mathbf{f}} / \mathbf{c m}^{\mathbf{3}}\right)\end{array}$ & \% Porosity \\
\hline AA7075 & - & 2.80 & 2.74 & 2.0 \\
\hline $10 \%$ B4C-90\% AA7075 & 10 & 2.77 & 2.50 & 9.8 \\
\hline 20\% B4C-80\% AA7075 & 20 & 2.74 & 2.43 & 11.4 \\
\hline
\end{tabular}

It was observed that, as the volumetric reinforcement ratios increased, the experimental specific gravities of the composite materials decreased. Specific weight and porosity experiments were carried out at the Marmara Research Center of TÜBITAK, and the theoretical and experimental specific weight results of the experiment specimens were compared. As a result of this comparison, the porosity levels were found to be high. This was thought to be due to the length of mixing time and low application rate of compression pressure.

\subsection{Mechanical Test Results}

\subsubsection{Three-Point Bending Test}

In this study, three composite materials were produced from each reinforcement ratio to be used in the experiments, and additionally, to make a comparison, three test specimens were produced from the non-reinforced composite material under the same production conditions. Three-point bending tests were applied to these test samples. The bend strength of the samples was calculated with the help of the equation specified in the ASTM B528-05 standard.

When the three-point bending test results of the non-reinforced AA7075 aluminum alloy were examined, the mean bending strength was found to be $268 \mathrm{~N} / \mathrm{mm}^{2}$. When the three-point bending test results applied to the $10 \%$ and $20 \%$ by volume particle-reinforced AA7075/B $4 \mathrm{C}$ composites were examined, it was seen that the mean bending strength of the $10 \%$ reinforced composites was 194.6 $\mathrm{N} / \mathrm{mm}^{2}$, and the mean bending strength of the $20 \%$ reinforced composites was $206.3 \mathrm{~N} / \mathrm{mm}^{2}$ (Figure 3 ). As the reinforcement ratio increased, bending strength increased, but due to the high porosity rates, there was a reduction in comparison to the non-reinforced aluminum alloy.

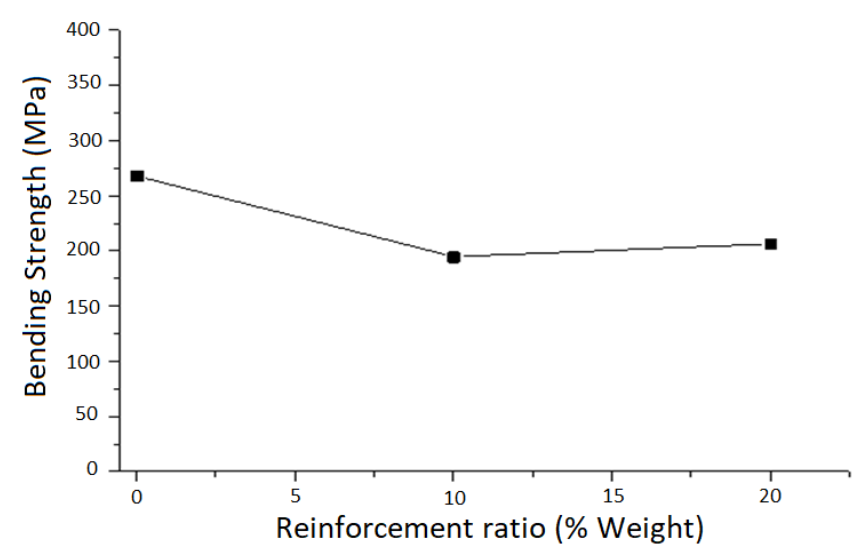

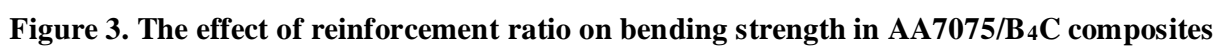




\subsubsection{Compression Experiments}

When the compression test results of the AA7075 non-reinforced aluminum alloy were examined, it was seen that the mean compressive strength was $500 \mathrm{~N} / \mathrm{mm}^{2}$. When the compression test results applied to the $10 \%$ and $20 \%$ by volume particle-reinforced $\mathrm{AA} 7075 / \mathrm{B} 4 \mathrm{C}$ composites were examined, it was observed that the mean compression strength of the $10 \%$ reinforced composites was $493.7 \mathrm{~N} / \mathrm{mm}^{2}$, and similarly, the mean compression strength of the $20 \%$ reinforced AA7075/B $4 \mathrm{C}$ composites was found to be $360 \mathrm{~N} / \mathrm{mm}^{2}$ (Figure 4). It was seen that there was a decrease in compression strength after increasing the $\mathrm{B}_{4} \mathrm{C}$ reinforcement ratio to $20 \%$ by volume.

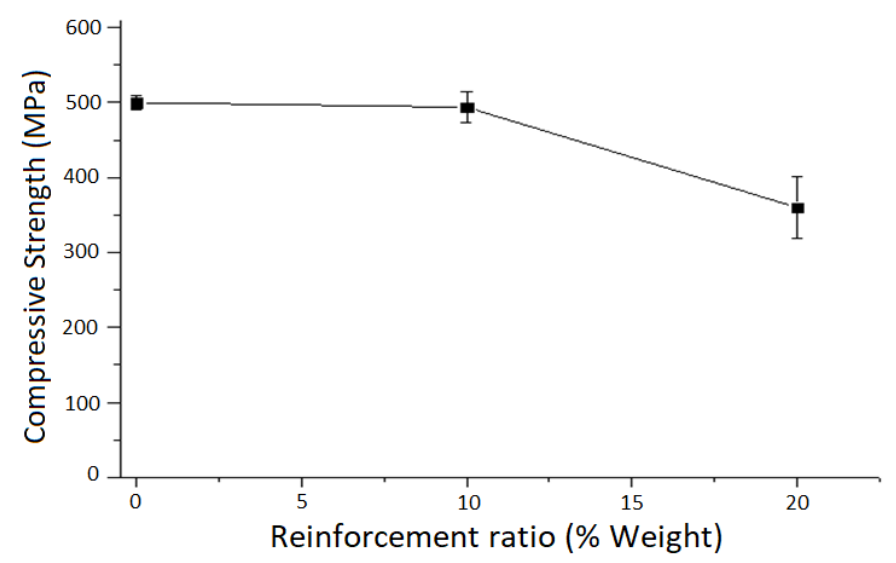

Figure 4. The effect of reinforcement ratio on compression strength in $A A 7075 / B_{4} C$ composites

\subsubsection{Hardness Experiments}

When the hardness test results of the non-reinforced AA7075 aluminum alloy were examined, the mean hardness was found to be $70 \mathrm{BSD}$. When the hardness test results applied to the $10 \%$ and $20 \%$ particle-reinforced $\mathrm{AA} 7075 / \mathrm{B}_{4} \mathrm{C}$ composites were examined, the mean hardness of the $10 \%$ reinforced composites was found to be $107 \mathrm{BSD}$, while it was $127 \mathrm{BSD}$ for the $20 \%$ reinforced composites (Figure 5). In the study, as the reinforcement material had a good wettability by aluminum, it was seen that the mean hardness value increased as the reinforcement ratio increased.

In their study, Hasırc1 and Gül (2010) produced averagely $25-\mu \mathrm{m}$-sized Al by means of powder metallurgy, they produced $10 \%$ and $20 \% \mathrm{~B}_{4} \mathrm{C}$-reinforced $\mathrm{B}_{4} \mathrm{C} / \mathrm{Al}$ composites, and they investigated the change in hardness depending on the reinforcement volume ratio. They found the results of approximately $46 \mathrm{HV}$ for the $10 \% \mathrm{~B} 4 \mathrm{C}-\mathrm{Al}$ reinforced composite and about $55 \mathrm{HV}$ for the $20 \% \mathrm{~B} 4 \mathrm{C}-\mathrm{Al}$ reinforced composite [2]. Since the hardness values of composites produced by powder metallurgy are less than $80 \mathrm{HV}$ and $76 \mathrm{BSD}$, which is the lowest hardness value in hardness conversion tables, no exact comparison could be made with the hardness values found in this study. However, the fact that the hardness values in this study were seen in the hardness conversion tables shows that the hardness values of the composites produced by powder metallurgy were lower than the hardness values in this study. 


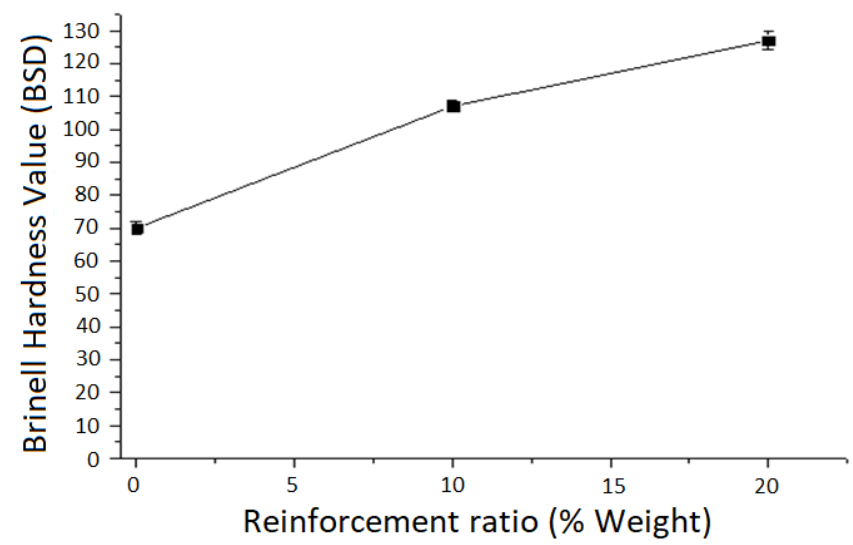

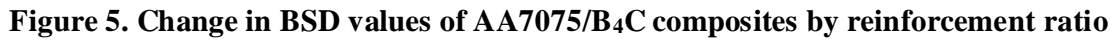

\subsubsection{Microstructure Examinations}

Whether there is a mechanical or chemical bond between the reinforcement phase and the matrix in the composite materials produced may be understood by examining whether the reinforcement phase is homogeneously dispersed in the matrix. The microstructures of the test samples were examined by SEM images taken at different magnification rates.

The SEM microstructure images of the $10 \%$ and $20 \% \mathrm{~B}_{4} \mathrm{C}$-reinforced $\mathrm{AA} 7075 / \mathrm{B}_{4} \mathrm{C}$ composites are given in Figure 7. In the composites shown in Figure 7 (a) and (b), it is seen that the reinforcing material was homogeneously distributed, and while looking at x40 and x2500 magnifications, it is seen that the $\mathrm{B}_{4} \mathrm{C}$ particles were wetted well by aluminum. When the images are examined, it is observed that the $\mathrm{B}_{4} \mathrm{C}$ particles were well-surrounded by aluminum, and there were no images related to pores and flocculation. This shows that the reinforcement was distributed homogeneously in the matrix, and a mechanical bond was formed between the reinforcing material and the matrix material.

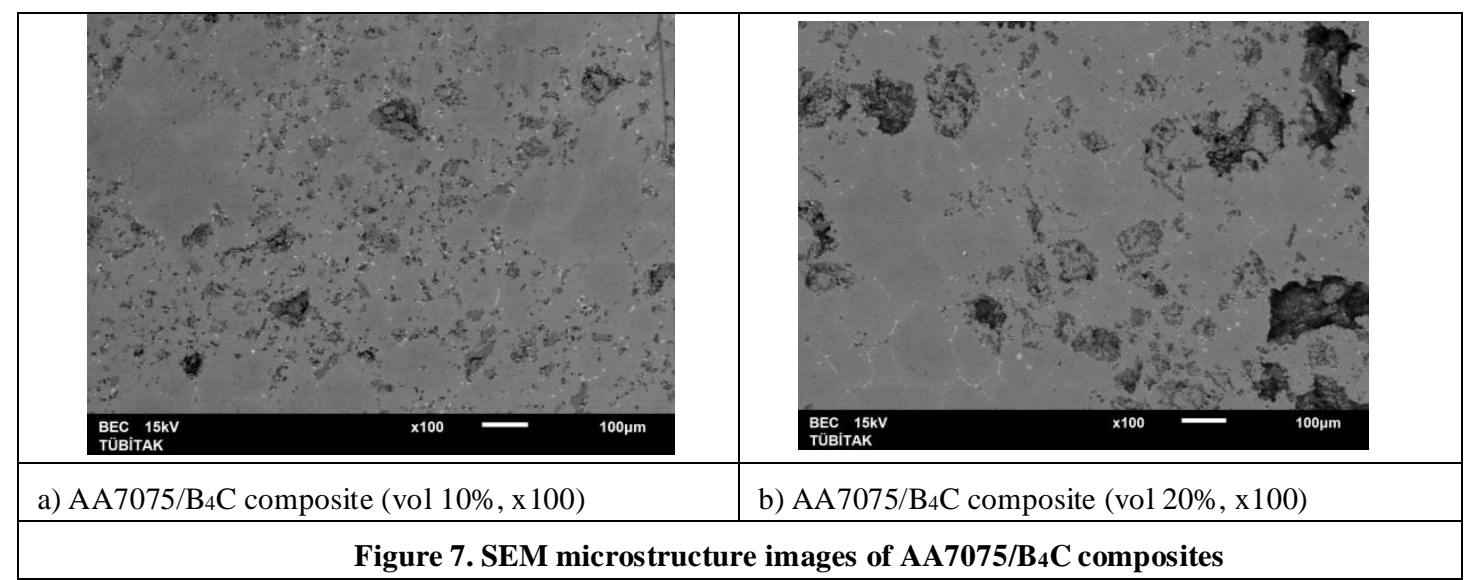

In the EDS analysis given in Figure 8, it was observed that the reaction products formed at the interface of the matrix material with the reinforcement. Thus, the formation of a chemical bond was confirmed. We observed $\mathrm{Al}$ peaks that represented the aluminum constituting the matrix material, $\mathrm{B}$ and $\mathrm{C}$ peaks that constituted the $\mathrm{B} 4 \mathrm{C}$ material and $\mathrm{O}$ peaks that confirmed the reaction products. 


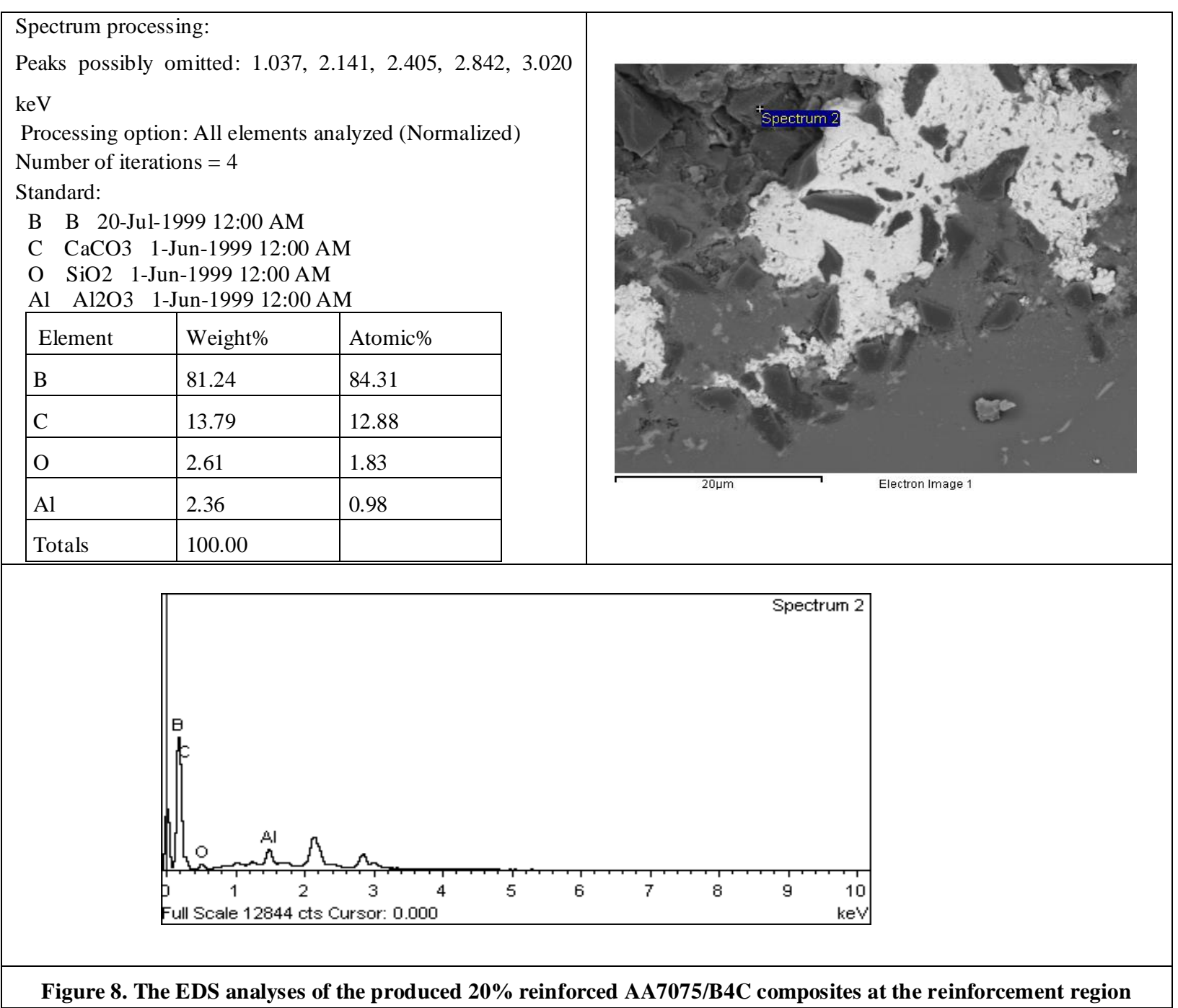

With the XRD analysis for produced 20\% AA7075/B 4 C composites with $20 \%$ reinforcement, it was determined that $\mathrm{Al}_{3} \mathrm{BC}$ and $\mathrm{B}_{2} \mathrm{O}_{3}$ weighted reaction products were formed at the interface of the reinforcing material and both matrix materials, and there was a chemical bond between the reinforcement and matrix materials as shown in Figure 9. Additionally, it was seen in the XRD analysis given in Figure 10 that the heat treatments performed to increase the wettability of $\mathrm{B}_{4} \mathrm{C}$ powders by Aluminum were successful. In this analysis, $\mathrm{B}(\mathrm{OH})_{3}$ reaction products were formed on the $\mathrm{B}_{4} \mathrm{C}$ powders.

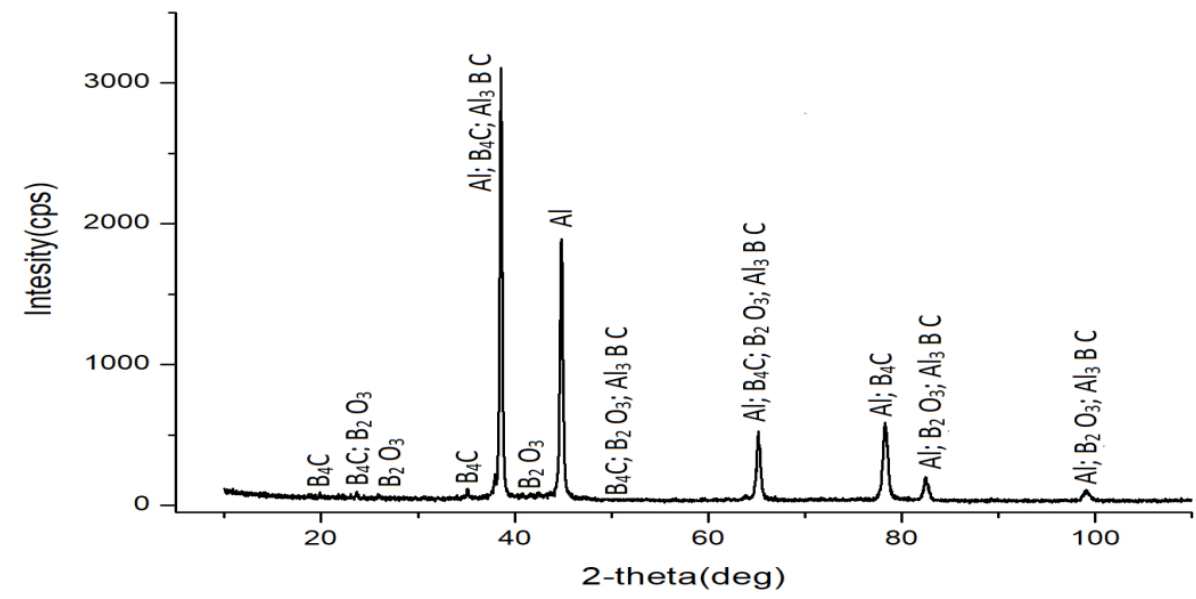

Figure 9. XRD analysis on $A A 7075 / B_{4} C$ composite 


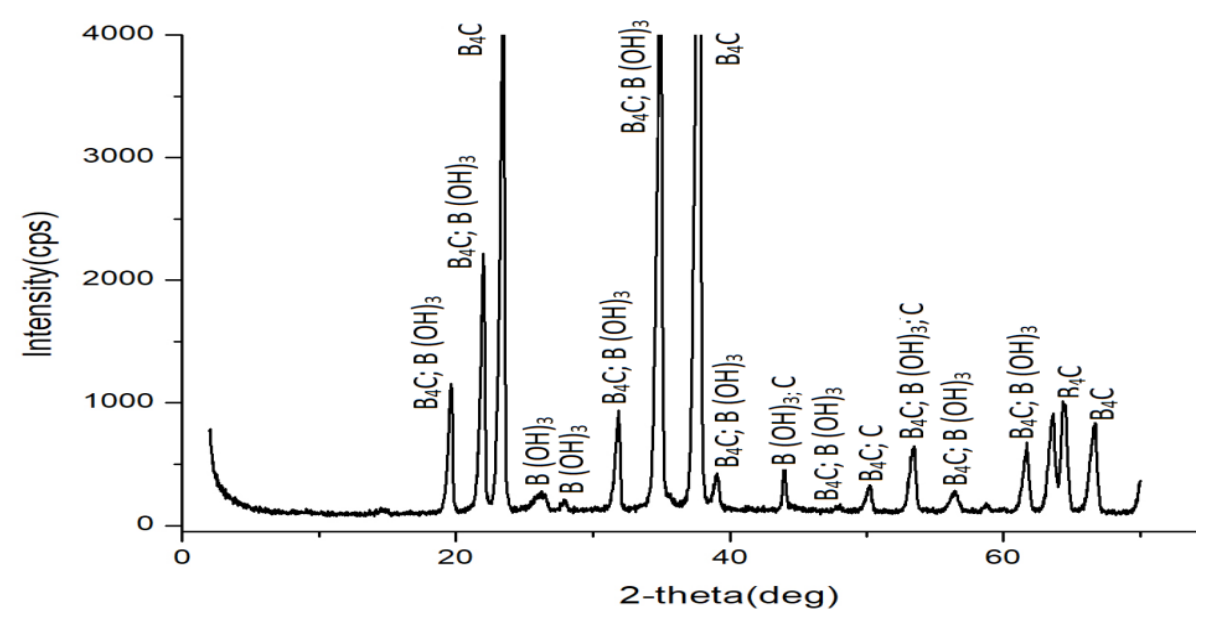

Figure 10. XRD analysis on $\mathrm{B}_{4} \mathrm{C}$ powders that were heat-treated

\section{Conclusion}

In this study, composite materials were produced by reinforcing the AA7075 Aluminum alloy with the $\mathrm{B}_{4} \mathrm{C}$ reinforcing material. Composite materials were produced by applying the semi-solid stirring method and a solidification process under pressure in the mold. Mechanical tests were performed to determine the bending and compression strength of the composite materials that were produced, and as a result, microstructure analyses were performed. The results that were obtained are summarized as follows.

a) It was found that the reinforcing material could be mixed homogeneously into the matrix material by using the semi-solid stirring method, and it was seen that no problems such as flocculation, resolution, sedimentation and excluding the reinforcement out of the matrix occurred.

b) Heat treatment of the $\mathrm{B}_{4} \mathrm{C}$ reinforcing material resulted in formation of reaction products on $\mathrm{B}_{4} \mathrm{C}$, and thus, the good wettability of the reinforcing material by the aluminum was improved.

c) When the SEM images of microstructures were examined, it was seen that the $\mathrm{B}_{4} \mathrm{C}$ reinforcement particles were well-surrounded by the matrix material with the effects of semi-solid stirring and solidification under pressure, and there was a mechanical bonding between the reinforcement and the matrix.

d) It is thought that the interface properties of the composites produced were improved; however, depending on the high porosity ratio, the improvement in the interface properties could not be transferred onto the mechanical properties sufficiently.

e) As in conventional alloys, porosity affects the mechanical properties negatively in the composite materials produced, and this effect is considerably higher than that of conventional alloys.

f) While a liquid or semi-solid stirring process leads to increased gas solubility, the vortex formed during stirring causes the gas to be confined to the liquid alloy. Hence, this shows that the speed of the stirrer and its position in the melt have importance.

g) When the hardness values of the $10 \%$ and $20 \% \mathrm{~B}_{4} \mathrm{C}$-reinforced composites produced by the semisolid stirring method were investigated, the semi-solid mixing method was found to be successful.

\section{Acknowledgment}

This work was supported by the Coordinator of Trakya University's Scientific Research Project (TUBAP Project No: 2013/12). 


\section{References}

[1] Toptan, F., Production of High Wear Resistant B4C Particle Reinforced Aluminium Matrix Composites, Yildiz Technical University, Department of Metallurgical and Materials Engineering, Ph.D. Thesis, İstanbul, 2011.

[2] Hasırc1, H. ve Gül, F. (2010). Investigation of abrasive wear behaviours in B4C/Al composites depending on reinforcement volume Fraction, SDU International Technologic Science, 2 (1), 1521.

[3] Akın, G., Production Of Boron Carbide Reinforced Aluminium Matrix Composites Using Powder Metallurgy Method And Investigation Of Their Mechanical Properties, İstanbul Technical University, Instıtute of Science And Technology, Master of Science Thesis, İstanbul, (2006).

[4] Pul, M. (2019). The Effect on Mechanical Properties of Reinforcement Amount at $\mathrm{B}_{4} \mathrm{C}+\mathrm{TiB}_{2}$ Reinforced Al 2024 Based Composites Produced by Powder Metallurgy, International Journal of Engineering Research and Development, 11 (1), 87-99.

[5] Taşc1, U., Gökmeşe, H., Bostan, B. (2013). AA 2014 Al Matrisli B4C Parçacık Takviyeli Kompozitlerin Mikro Yapı ve Aşınma Davranışının İncelenmesi, Gazi Üniversitesi Fen Bilimleri Dergisi Part:C, Tasarım ve Teknoloji, 1 (4), 161-168.

[6] Karabulut, H., Effect of Mechanical Alloying Duration on Composite Properties In Production Of $\mathrm{Al}_{2} \mathrm{O}_{3}$, SiC And $\mathrm{B}_{4} \mathrm{C}$ Particulate Reinforced Composite By Powder Metallurgy Method, Gazi University, Institute of Science And Technology, Ph.D. Thesis, Ankara, 2011.

[7] Topcu, İ., Dikici, M., İpek, C., Investigation of Wear Properties of Ceramic Reinforced Aluminum Based Metal Matrix Composites, 6th International Symposium on Innovative Technologies in Engineering and Science 09-11 November 2018 (ISITES2018 Alanya - Antalya - Turkey)

[8] Motorcu, A. R., and Ekici, E., (2016) Evaluation of drilling $\mathrm{Al} / \mathrm{B} 4 \mathrm{C}$ composites with carbide drills, Pamukkale University Journal of Engineering Sciences, 22(4), 259-266

[9] Pul, M., Calin, R., Citak, R. (2011). An Investigation of Surface Quality of Turning in Al matrix $\mathrm{MgO}$ Reinforced Composite Materials, Journal of the Faculty of Engineering and Architecture of Gazi University, 26 (1), 81-88.

[10] Arslan, D., Gürü, M. (2013). Production of Boron Carbide by Mechanochemical Method and Investigation of Usability on The Aluminium Based Composite Material, Journal of the Faculty of Engineering and Architecture of Gazi University, 28 (4), 875-883.

[11] Çolak, N. Y., Turhan, H. (2016). The Investigation of Microstructure and Mechanical Properties of $\mathrm{AlSi} / \mathrm{B} 4 \mathrm{C}$ Composites Produced by Using Powder Metallurgy Method, Science and Eng. J of Firat Univ, 28 (2), 259-266.

[12] Çelik, Y. H., Kılıçkap, E., Yenigün, B. (2018). The Effect of Contact Pressure and B4C Ratio on Hardness and Wear Behaviours in Al-Matrix Composites Produced by PM Method, Science and Eng. J of Firat Univ., 30 (1), 33-40.

[13] Tosun, N., Kuru, C., Altintas, E. (2010). Investigation Of Surface Roughness In Milling With Air And Conventional Cooling Method, Journal of the Faculty of Engineering and Architecture of Gazi University, 25 (1), 141-146.

[14] Tuncer, N., Tasdelen, B., Arslan, G. (2011). Effect of Passivation And Precipitation Hardening On Processing And Mechanical Properties Of $\mathrm{B} 4 \mathrm{CAl}$ Composites, Ceramics International, 37 (7), 2861-2867. 
[15] Motorcu, A. R., Ekici, E. (2016). Evaluation of drilling Al/B 4 C composites with carbide drills, Pamukkale University Journal of Engineering Sciences, 22 (4), 259-266.

[16] Gökmen, U. (2016). Joining of Al 2024 Based B4C/SiC Particle-Reinforced Hybrid Composites with TIG Welding, Çukurova University Journal of the Faculty of Engineering and Architecture, 31 (1), 69-77.

[17] Seçilmiş, K., Investigation of Wear Behaviors of Al Matrix Composites Reinforced With Different $\mathrm{B}_{4} \mathrm{C}$ Rate Produced by Powder Metallurgy Methods, Batman University, Institute of Science And Technology, Master of Science Thesis, Batman, (2017).

[18] Ahlatçı, H., Candan, E. ve Çimenoğlu, H. (2003). The Effect of SiC Size on The Wear Behaviour Of $60 \mathrm{Vol} \%$ SiC-Al Composites, ITÜ̈ dergisi/d mühendislik, 2 (3), 37-42.

[19] Ekici, E., The manufacture of aluminium matrix composites with $\mathrm{B}_{4} \mathrm{C}$ reinforcing element and addition of graphite and the analysis of mechanical features and their machinability on milling, Gazi University, Institute of Science And Technology, Ph.D. Thesis, Ankara, 2012.

[20] Atik, E., Ünlü, B.S., Sen, O., Çavdar, U. (2006). Investigation of Wear Strenght and Mechanical Properties of Particle Reinforced AlSi12CuNiMg Composites, C.B.U. Journal of Science, 2 (2), 75-87.

[21] Ürkmez, N., Production of $\mathrm{AlMg} 3 / \mathrm{SiCp}$ composites and investigations of variations in mechanical properties, Yildiz Technical University, Instıtute of Science And Technology, Ph.D. Thesis, İstanbul, 2004.

[22] Yakut, R., and Ürkmez Ürkmez T., (2018), Productıon of AA7075 / B4C / SiC Hybrid Composite Materials By Semi-Solid Stırring Method, 1st International Engineering And Technology Symposium (1st Iets) 03-05 May, Batman / Turkey

[23] Akgün Kayral, S., (2017). Production Of Tib2-B4C Composite Powders by The Carbide Boronızıng Process, Engineering Sciences (NWSAENS), 12 (3), 141-148 